\title{
HVAD ER ET MUSEUM? EN SEMIOTISK UNDERSØGELSE
}

\author{
Per Aage Brandt
}

I antikken var et «museum» et forskningscenter (museet i Alexandria). Renassancen fastholdt den samme betydning af ordet: et sted, hvor kunst, litteratur og videnskab regelmessigt dyrkes. I det 18. ärhundrede bliver den moderne betydning almindelig: "et etablissement, som rummer klassificerede samlinger af genstande, der frembyder en historisk, teknisk, videnskabelig eller kunstnerisk interesse, og som gør det med henblik på deres konservering og deres fremvisning for publikum" (Petit Robert).

Museer i denne sidste forstand synes at være steder, der forbinder præparerede (plejede og redigerede) genstandssamlinger med kulturelle offentligheder, som gennem dem træder i forbindelse med historiske forhold. Tegn (genstandssamlinger) tolkes (af offentligheder) og betyder noget (historiske forhold). Man kunne da tro, at alle steder, hvor mennesker gør tegn gennem genstande, som indsamles til formålet, er museer.

Biblioteker er dog ikke museer i moderne sprogbrug. De rummer ganske vist samlinger, men "fremviser» ikke blot deres præparerede genstande, bøgerne, idet de tillader en vis brug af dem, nemlig læsning. Museets genstande skal åbenbart kun beskues, ikke bruges (slides); museet gør dem tilgængelige for sansning - især beskuelse - og hvad deraf følger (tænkning), men ikke for anvendelse, slid, konsumption. En restaurant er heller ikke et museum; genstandssamlingen ville være opregnet på menukortet, men hver ret for- svinder i sansningen (spisningen). Biblioteker og restauranter serverer så at sige deres genstande; disse er ikke originaler, og derfor kan de konsumeres; de henviser nok, men ikke fordi de materielt set er rester af de forhold, de henviser til. Museets genstandssamlinger synes derimod at skulle udgøres af originale rester, spor, efterladt af den historie, der henvises til. Selv om man måske kan nøjes med at fremvise kopier. Er filmmuseet så et museum? Det er måske et grænsetilfælde for at «se» en film er jo også at «læse» og «bruge» den. Er enhver biograf så ikke et museum? Nej, for den rummer ikke en samling, den er snarere et gennemstrømningssted for genstande. Samlingen synes at skulle være stationær. I modsætning også til udstillinger $\mathrm{i}$ almindelighed.

Denne dobbelte ejendommelighed 1) ren fremvisning uden funktionel brug og 2) genstandens henvisning til en samling - er værd at overveje. Lad os hengive 
18 os til lidt imaginær variation, som det kaldes. Er en encyklopædi et museum? Et vidensmuseum? Ja, på en måde. Den henviser jo til en historisk videnstilstand, nutidig eller fortidig. Der mangler blot et materielt sted, eftersom en bog, som er en encyklopædi, eksisterer på en anden façon, immaterielt. Er enhver ordbog så et museum, et lille ord-museum? Ja, på de samme betingelser. Især hvis der bag bogens ord-samling står en levende gruppe mennesker, filologer, som vedligeholder den - idet de besørger nye udgaver. Hele det immaterielle "museum» er her i øvrigt til salg; vil man engang på samme måde kunne anskaffe sig «museer» på disketter eller video-CD? Regelmæssigt opdateret af hvert museums vedligeholdere...

Her har vi således endnu en betingelse. Et "dødt museum» - hvis vedligeholdere er forsvundet - er snarere en genstand, som selv kan anbringes i et museum. Et "levende museum» beskæftiger nødvendigvis mennesker. Er på den anden side en zoologisk have et museum? Er den et zoologisk museum? Nej, for samlingens genstande er levende i "haven"; det mà de ikke være, ser det ud til. En hunde- eller katteudstilling er heller ikke et museum. I et levende museum skal genstandene vare døde. Men deres vedligeholdere skal vare $i$ live. En kirkegård, da? Nej, for genstandene, de døde, vises ikke frem; de vedligeholdes heller ikke, tværtimod. Gravstenene gør måske, men de udgør ikke samlinger, for de kan ikke vilkårligt flyttes efter en planlagt fremvisnings kriterier. Et «menneske-museum» - som dét i Paris (Musée de l'Homme) - kan ikke ubesværet udstille udstoppede mennesker, selv om man faktisk undertiden har gjort det, når de var tilstrækkeligt "primitive». Det fører i vore dage til etnisk-etiske konflikter. I så fald tyr man til simulakrer; vokskabinetter er gode eksempler. Dette sidste punkt rejser et spændende problem: skal genstandene være "ægte» $i$ et museum? Ảbenbart ikke nødvendigvis. Vokskabinetter og planetarier viser ikke ægte stars og stjerner. Man kunne foreslå at sige, at disse sidste "stjerner" - politikere, skuespillere, kunstnere, himmellegemer netop er ægte, når de er uægte. De er nære, når de er fjerne. De er nutidige, når de er fortidige. Derfor er simulakrerne fuldt tilfredsstillende. Men et geologisk museum fordrer rigtige sten - ved siden af billeder af f. eks. bjerge, der ikke kan flyttes og rummes i lokalerne. Det samme gælder individ-museer som Blixens eller Andersens stuer - vi vil helst have rigtige ting (blyanter, tandbørster), der har rørt ved eller tilhørt originalen, ved siden af billeder af det forsvundne menneskebjerg. Hvis det er farligt at vise den ægte vare, vil vi have et løfte om, at den befinder sig i arkivet. Hvis den er forsvundet (som guldhornene), vil vi forsikres om, at den rigtignok har været der, eller i det mindste har været til. Og om, at dens repræsentant ligner den så godt som muligt. Hvad så med spejlkabinetter? Er det museer? Det er måske ligefrem anti-museer: det er publikum selv, der udstilles, og spejlenes simulakrer ligner demonstrativt ikke-godt; man finder dette morsomt, falsk og meningsløst. I modsætning til alvorligt, sandt, meningsfuldt. Museer er ikke morskabshuse; det direkte modsatte af morskaben er den museale, seriøse konvention om sandhed og xgthed - sande udsagn om ægte varer, i det mindste som regulativ idé (som Kant sagde). Man tilstræber sådanne udsagn. Museet er en sådan hensigtserklæ- 
ring, opført som en helst lidt imposant bygning på et mere eller mindre motiveret sted.

Der er altså en sandhedsfunktion, som skal henvise til eksistens, eventuelt (kopiers) lighed og desuden - hvilket sikres ved en beskrivelse - også en afgørlig og realistisk mening: hvad blev en given dims brugt til? Det er - bortset fra kunstværker - ikke nok, at en genstand blev brugt til at udstille på et museum, den kan ikke have vandret fra museum til museum altid. Uden for museet skal der ligge en ikkemuseal virkelighed, hvis egenskaber giver de museale genstande mening, og denne virkelighed skal i øvrigt være relativt utilgængelig uden for museet; i almindelighed en fortidig virkelighed. Ellers kunne vi virkelig sige, - som vi undertiden siger for sjov - , at vore ideligt gentagne gøremål, vore kedsommelige rutiner og dertil hørende genstande, gør selve tilværelsen til et museum, ja, hele kloden med alt, hvad den omfatter... Selv turisten, der ellers netop opfatter kloden som noget i retning af et museum, fordi han selv er på ferie og ikke på arbejde, holder sin egen funktionelle hverdagsvirkelighed udenfor. Ingen museer uden et grundlæggende skel mellem en verden udenfor og en scene indenfor. Her er vi tilbage ved princippet: nok se, men ikke bruge; nok sanse og tænke, men ikke handle og slide ned; nok vise, men ikke tilbyde (rigtigt). For det, der vises frem, er i princippet tabt eller på anden måde fjernt og ikke direkte tilgængeligt.

$\mathrm{Nu}$ ved vi allerede lidt om museer. Lad os forsøge at resumere. Et «normalt» museum består åbenbart af en række komponenter. For det første skal der være et "etablissement», dvs. et fysisk sted og en social institution, som sikrer en levende bemanding af det. For det andet skal der være en genstandssamling på dette sted, og genstandene skal være døde eller naturligt livløse, og de skal henvise til samlingen udfra et eller andet princip, som atter henviser til noget uden for museet, som har eksistens, kan afbildes og tilskrives en mening. For det tredie skal genstandene i nogen grad vises frem, således at de er sanseligt tilgængelige for en kvantitativt og kvalitativt ubestemt mængde besøgende. Disse skal herved kunne blive opmærksomme på noget ekstramusealt, som har en vis interesse $\mathrm{i}$ kraft af dets historiske eksistens, synlighed og mening for mennesker. Der skal på museet netop være tale om «besøg», ikke om beboelse eller gæstgiveri (Disneyland er også derfor et grænsetilfælde). Kustoder sikrer, at publikum ikke slår sig ned med henblik på beboelse. "Besøget» sikrer ligesom i andre sammenhænge tilstedeværelsens flygtighed og dermed åndfuldhed, dets kognitive, ikkepragmatiske karakter. Der skal tænkes eller drømmes, ikke leves, i museet. Af hensyn til overlevelsen på meget kort sigt har mange museer dog kantiner eller kafeer. Men ingen har mig bekendt f. eks. grøntsagsmarkeder.

De tre omstændigheder kan siges at angå Afsenderen (det socio-fysiske sted), Meddelelsen (genstandssamlingen), Modtageren (de besøgende). Men hvis museet således er en art kommunikation, er det en meget speciel form for kommunikation. Afsenderen er stedfast, stationær, mens Modtageren er mobil. Selv en rullende udstilling udgår fra en stationær samling. Meddelelsen er klart påpegende, eller som det hedder med et teknisk udtryk fra sprogvidenskaben, deiktisk - 
20 den er ækvivalent med en sætning, som siger: se, her er en $x$. Dette $\mathrm{x}$ er hentet $\mathrm{i}$ et inventar $\{\mathrm{x}\}$, som selv er hentet $\mathrm{i}$ en virkelighed uden for den museale deiksis. Inventaret $\{\mathrm{x}\}$ skal være resultatet af et, helst stadig igangværende, studium. Studiet har et genstands-felt, som skal være udtrykkeligt afgrænset; det må ikke slet og ret være hvadsomhelst, der udstilles; dette er altid sprogligt sikret i museets institutionelle bestemmelse (i modsætning til den gale, fetichistiske samlers tilfældige skrammel, bric-à-brac). Et museum for $\mathrm{f}$. eks. komplet uforståelige ting, således bestemt i vedtægten, et mirakelmuseum, ville formentlig derfor være absurd: her er intet studium muligt. Intet at forstå. Raritetskabinetter er grænsetilfælde. Genstandssamlingen er organiseret udfra et studiums samlende fortolkende begreber. Et museum implicerer en hermeneutik.

Men hvert $\mathrm{x}$ kan anskues på to måder, dels som et spor af noget, et såkaldt indeks, relateret til eksistensen af noget begribeligt og fortolkeligt, og dels som et billede af dette noget, et såkaldt ikon, relateret til nogets opfattelige, især synlige, egenskaber. Disse to måder gør hvert x til en slags logisk sætning med indekset som subjekt og ikonet som prædikat. "Se, dette er en (typisk?) x, og sådan ser den ud». Subjektet er den fortolkede genstand, og prædikatet er den synlige genstand (den samme).

De fleste museer udbygger naturligvis den uskrevne $\mathrm{x}$-sætning med udtrykkelige tekster, der styrer opmærksomheden mod denne non-verbale, fremvisende sætnings intention hos den museale afsender. Under alle omstændigheder er publikum talende. Der består en særlig spænding mellem museets non-verbale og verbale sætningsmængder. Især i betragtning af, at disse tekster atter er bestemt af museets rum-tid, og at de fordeler sig og danner betydningsfelter, svarende til rummets opdeling og de planlagte eller mulige veje for beskuerne gennem det. $\mathrm{Da}$ de besøgende ikke kan se alle fremviste genstande på én gang, må denne museets symbolske dimension tages i betragtning som en relation mellem mulige fysiske gennemløb og dertil hørende tekstforløb. Man kunne tale om en variabel museal fremstillingsstrategi, som f. eks. adskiller en rent tidslig eller geografisk sammenkædning af genstande fra en tværgående og sammenlignende, tematisk bestemt sammenstilling. Eller en bevægelse fra originaler til stadig fjernere simulakrer... Eller et forløb fra de mest indlysende ting til de mest gådefulde. Selv om et museum er helt tavst, er selve dets fremvisningsstrategi stadig symbolsk og talende, fordi den fører beskuerne gennem rummet $\mathrm{i}$ tid og dermed frembringer "tekstlige» sammenkædninger af $\mathrm{x}$ sætningerne. En estetik for disse museale strategier burde derfor udvikles; vi er ikke på bar bund, men museernes professionelle kunne givetvis belære offentligheden meget mere om deres overvejelser.

Museets hermeneutik og æstetik må hænge strategisk sammen: dets dobbelte, både fortolkende og fremvisende, praksis må som $\mathrm{i}$ enhver tegngivning være kendetegnet af en mere eller mindre funktionel regelmæssighed. Jeg foreslår her prøvende en simpel, måske brugbar klassifikation: hermeneutikken kan være forbundet med æstetikken på tre måder. Enten $\mathrm{A}, \mathrm{B}$ eller C. - A er den, der kan siges at frembringe det gennemsigtige museum - fremstillingen er «indlysende» i betragtning af fortolk- 
ningen, idet det, der vides om genstandene, og det, der vises, er ordnet på samme måde. Hvis denne viden f. eks. gælder historisk samhørighed og forskel, vil den tilsvarende visen indrette museets rum som en afbildning af tiden i epoker, der følger hinanden lineært eller forgrenende. Kunstmuseer bærer sig i almindelighed sådan ad. Hvis hermeneutikken er geografisk, bliver fremstillingsrummet selv et art kort. Princippet er gennemsigtigt - og ofte også lidet attraktivt, fordi det er uden overraskelser; men på den anden side er det let at orientere sig i et sådant museum. Let og en kende kedeligt, vil man sige. Også fordi det må være en indlysende viden, der omsættes så indlysende $\mathrm{i}$ fremstillingsrummet. Hvis grammatikker er sprog-museer, der bygger på indlysende klassifikationer, er de gode eksempler på denne strategi, hvor hermeneutikken altså dominerer over æstetikken. - B er den modsatte organisationsform: vi kan kalde den det underholdende museum. Her er det genstandenes synlige egenskaber, der får lov at bestemme fremstillingens orden. Uigennemskuelige, mærkværdige eller på anden måde fascinerende objekter defilerer $i$ et spraglet optog, der som i en offentlig parade afstemmer former, størrelsesforhold, farver og underholdningsværdi i øvrigt efter hinanden uden hensyn til, hvad der vides om samlingens indre sammenhæng eller mening. Resultatet er en sight-seeing eller en postkortstand i arkitektonisk format, lige så indbydende eller umiddelbart fængslende, som den er adskilt fra ethvert studium. En del af personalet er tilsvarende beskæftiget med præsentationen alene, ikke med genstandsstudiet eller samlingens pleje, men med publikums, med dets otium, fritids- udfyldning. Visse dele af A-museerne er undertiden indrettet efter princippet $B$ af hensyn til entréindtægterne eller et behov for mærkbar interesse fra omverdenens side. - $\mathrm{C}$ er endelig den strategi, som lader hermeneutikken og æstetikken indgå i en uafgjort dialogisk dyst; man kan kalde den det undersøgende museums stilart. Her er det måske tematiske sammenstillinger af genstande, der indbyder til en sammenligning af forskellige formtyper i fremtrædelsen, mens formfællesskaber samtidig kan pege på mulige analogier eller ejendommelige forskelle i genstandenes kendte anvendelser eller oprindelser. Det formodet forskelligartede kan vises at fremtræde som formmæssigt ensartet, og det forskelligt formede måske henvise til den samme anvendelse eller oprindelse; i begge tilfælde stilles nye spørgsmål om forskelles og ikke-forskelles årsager. Studium (afsender) og otium (modtager) danner en åben, legende og alvorlig enhed, en kommunikation, i hvilken også mindre indlysende fortolkninger kan luftes, og mindre oplagte fremstillingsmåder kan afprøves. Mens æstetikken i og for sig er overflødig i A, og hermeneutikken er lige så overflødig i B, er begge meget relevante i C, hvor netop spændingen mellem dem kan - og sikkert er det eneste, der kan - udvikle dem begge. Projektionen går her $\mathrm{i}$ begge retninger: fra viden og ikke-viden til visen, fra visen til viden og ikke-viden. Visningen bliver en spørgen og en undersøgen. Det forekommer mig, at noget tilsvarende gælder i videnskabernes og kunstarternes "fremstillingsproblematik»; der spørges videre, hver gang et svar gives i og ved en fremstilling. Værkerne er åbne i deres lukkethed.

Det er fristende at forsøge en sammentænkning af de modeller, vi har benyttet i 
22 denne lille semiotiske undersøgelse af museet som betydningsmaskine, institution og "logik». Vi har benyttet imaginær variation - sammenligning af gode og dårlige eksempler - og teoretisk henvist til tegngivning, til kommunikation og specielt til den deiktiske logik i en genstandsfremvisning. Det er ikke klart for enhver, hvordan disse teoretiske størrelser hænger sammen; et fortsat arbejde med netop museet som praktisk udfordring kunne meget vel bidrage til en almen afklaring af sagen.

Det grundlæggende forekommer mig at være selve den principielle forbindelse med verden (W, den berømte "world»), som genstandene $(\mathrm{O}$, objekterne) etablerer for deres beskuere ( $S$, subjekterne).

$$
\mathrm{W} \rightarrow \mathrm{O} \rightarrow \mathrm{S}
$$

Museet systematiserer dette naturlige kommunikationsforhold, idet $\mathrm{O}$ genkendes som medlem af en genstandssamling $\{x\}$, der også begrunder et institutionelt sted, hvor $\mathrm{O}$, forstået som et $\mathrm{x}$ heri, udsættes for fortolkende tilberedning og derefter fremvisning. O-som-x bliver nu en art meddelelse i en kulturel kommunikation mellem på den ene side fortolkerne $\left(S^{\prime}\right)$ og fremviserne $\left(S^{\prime \prime}\right)$, på den anden side beskuerne $(S)$.

$$
\begin{aligned}
& \mathrm{O}<-\mathrm{x} \text { i }\{\mathrm{x}\}, \text { hvor } \\
& S^{\prime} \rightarrow\{\mathrm{x}\}<-S^{\prime \prime} .
\end{aligned}
$$

I den sidste relation har vi at gøre med en dobbelt Afsender S'/S", svarende til modsætningen mellem hermeneutik og estetik ovenfor, og også svarende til modsætningen mellem studium og otium, der blot udtrykker de to aspekter af beskuerens museale indstilling (han både tænker og drømmer). Det hermeneutiske studium henviser, refererer, til den erkendelige verden, W, hvorfra O kommer; det æstetiske otium refererer derimod til $S$ som sansende kapacitet. På denne måde forbereder museet genstanden til mødet med beskueren, idet $\mathrm{O}$ bliver et tegn med et æstetisk udfoldet udtryk og et hermeneutisk udfoldet indhold.

Alt dette kan vi sammenfatte i en dynamisk model, som stort set er hentet hos A. J. Greimas (aktantmodellen, fra fortælleteorien); $S^{\prime}$ er en art "modstander», der holder O tilbage, mens $S^{\prime \prime}$ er en art "hjælper», der trækker det frem mod beskueren; denne konflikt giver da et billede af museets iboende og $\mathrm{i}$ bedste fald produktive konflikt, som løses ved strategier som de nævnte (A, B, C). Vi kan simpelthen notere:

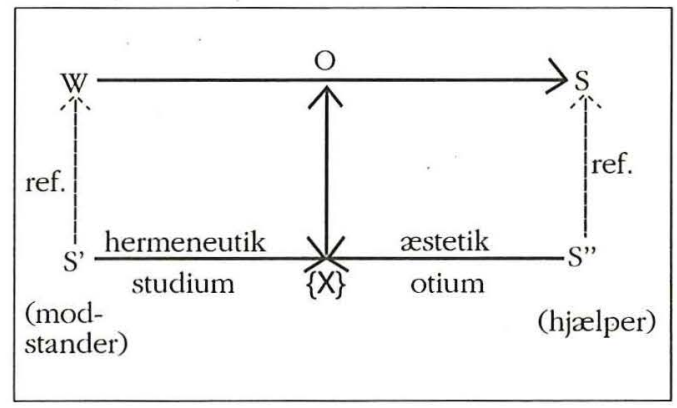

Der er således to kommunikationer i processen: den naturlige, som blot betyder, at verden tilskikker mennesker genstandsmæssige spor af sig selv - hvilket vi undertiden udtrykker ved at sige, at "tiden vil vise...", hvad der sker i vor virkelighed: "med tiden» viser ting sig, så man kan forstå noget af, hvad der foregår eller er foregået; og den kulturlige, som støtter den første ved at sammenholde $\mathrm{O}$ som $\mathrm{x}$ med andre $x^{\prime}$ er $i$ en samling, der interpreteres som tegn - med et æstetisk bestemmeligt udtryk og et hermeneutisk bestemmeligt 
indhold. Først er dette tegn et rent billede, et fastholdt ikon, der ligner det "rå» fænomen $\mathrm{O}$ og forbereder en mulig aflæsning. Dernæst går interpretationerne i gang, og tegnet bliver både et spor, et indeks, der henviser til noget eksisterende i W, og et symbol, som sætter en regelmæssig relation mellem en æstetisk fremtrædende formtype og en hermeneutisk forudset betydningstype. Indekset understreger det specielle ved netop dette $\mathrm{x}$; mens symbolet understreger dets træk som typiske for en kategori. Spændingen mellem indeks-værdien og symbol-værdien er kendetegnende for alle materielle genstande som objekter for beskuelse; de immaterielle genstande kan dog fastholde spændingen, når de er "dokumenter» (såsom breve, fotos), men bliver ellers overvejende symboler. Alle genstande bliver ikoner, når de fastholdes - således som det sker i museets "regi». Det samme sker med sproglige ytringer, fastholdt i skriftens "regi».

Museer er regier, en art Tidens Teatre, hvor dens forestillinger hjælpes på vej af mennesker, så at andre mennesker kan opfatte dem. Hvis virkeligheden lod sig opfatte direkte, og Tiden talte til os som et menneske, var museer overflødige. Jeg gætter på, at det moderne museum beror på en barok tanke, ifølge hvilken Tiden kun får mæle, når den teatraliseres - mens den ellers kun taler for døve øren. Døvheden kureres kun af den æstetiske indstilling, som netop fik de gamle til at påkalde sig Muserne $\mathrm{i}$ forbindelse med genstandssamlinger i huse. Uden Muser ingen refleksion, ingen virkelighedsopfattelse. Museer er menneskeligt nødvendige ligesom refleksionen. Men det fortjener en dyb og grundig overvejelse, hvorfor det kan forholde sig sådan. Og hvorfor det ikke er indlysende. Er vor horisont måske ikke mere barok end nogensinde?

Lad mig til sidst bemærke, at det nok spiller en rolle for tendensen til desertering af alt andet end de kunstfremvisende museer - hvis genstande jo så at sige selv gør det æstetiske arbejde for os - , at den globale mediekultur allerede synes at teatralisere vor virkelighed i overvældende grad, uden at den dog medfører nogen mærkbart dybere refleksion; den opleves tværtimod ofte som "de-realiserende», afskærende vor følelsesmæssige kontakt med det virkelige. Men dette standardiserede hurtig-teater veksler stort set alene mellem stilarterne A og B (mellem det gennemsigtige og det underholdende), som er de eneste, der ikke behøver at tage tid i betydningen kræve opmærksomhed. $\mathrm{Og}$ de elektroniske medier kræver end ikke transport: der er altid en skærm i nærheden. Museerne er langsomme medier i enhver henseende; de kan ikke speedes op til elektronisk standard: hus, krop og genstande er urokkeligt bundne til den levede tid, ligesom ethvert andet teater er det (heller ikke her er A- eller B-konkurrence med massemedierne mulig). Det museale genstandsteater kan til gengæld udvikle en undersøgende stilart (C), hvis refleksive kraft vil gøre alle skærmtrolderier til skamme: ved at indrette sig strategisk på denne tagen-tid vil den kunne give Tid som ingen anden instans $\mathrm{i}$ vor fælles tilværelse. Og uden denne udveksling af tid mod Tid er resten ikke realitet. Et sådant museum er et sine qua non. Museet er altså en art semiotisk og arkitektonisk opført realitetsprincip. Uden hvilket vi ville være lige så ilde stedt, som hvis vi ikke havde skrift til vore sprog. 


\section{SUMMARY}

What is a museum

The paper presents a contrastive analysis of the concept of Museum, and isolates its components: a collection of Objects, a collective Receiver, a historical Sender, a stationary Institution housing the collection and staging the Collection, a professional Staff responsible for research on the objects and retrieval of objects according to a selective Definition of the collection from reference to the historical sender, and finally a strategy of temporary Exposition developed by the same staff. This institutional frame is analysed as a conflict between the hermeneutic dimension (research and interpretation: the objects are signs of some historical facts) and the aesthetic dimension (guiding reception from the point of view of some principles of interest: beauty, enigma, entertainment). This reading of the meaning of museality follows the actantial schema elaborated by the semiotician A.-J. Greimas. A Museum is a Theatre of Time. Therefore, a hermeneutics of things past (opposing communication) meets an aesthetics of things present (guiding and helping communication) on the museal location (the stage). Instead of giving privilege to hermeneutics or aesthetics only (only Time, or only Theatre), the analysis pleads for maintaining the conflict and thus the open semiotic drama of truth and beauty in the encounter that any Museum offers as a medium allowing for a communication of the Past and the Present. The presentation of objects (originals or copies?; categorized according to hermeneutic or aesthetic criteria?; calling for thought or for pleasure?) is seen as an essential cultural task concerning human understanding of a world deeper than pure presence, articulating knowledge and perception, science and art.

* Artikelen «Hvad er et museum?» bygger på et oplæg med samme titel ved Museumshøjskolens kursus på Holstebro Højskole 5. - 10. september 1992: «Udstilling - forestilling», organiseret af Museumshøjskolens forstander Ole Strandgaard og støttet af Nordisk Kulturfond.

Per Aage Brandt er docent, dr. phil., forskningsleder ved Aarbus Universitet og Danmarks Grundforskningsfond. Leder af grundforskningsprogrammet Dynamisk Semiotik.

Adr: Center for Semiotisk Forskning,

Aarhus Universitet, Finlandsgade 26,

DK-8200 Aarhus N. Fax +45-86108228 